\title{
Fifteen years of publishing the papers on the impact of biological factors on hydrological processes in Biologia
}

\author{
Lubomír Lichner $^{1}$ - Katarína Hegedüšová ${ }^{2} \cdot$ Csilla Farkas $^{3} \cdot$ Miroslav Tesař $^{4} \cdot$ Kálmán Rajkai $^{5}$ \\ Published online: 25 May 2020 \\ (C) Plant Science Biodiversity Centre, Slovak Academy of Sciences 2020
}

\begin{abstract}
Special issue on the impact of biological factors on hydrological processes, edited by the authors of this Foreword, brings together 11 full-text papers on these complex interactions, ranging in scale from storing the water by lichen species to competing the nations for increasingly scarce water resources in securitized transboundary watersheds. In addition to these "boundary-scale" biohydrology papers, 4 papers assess the impact of land use on soil properties, 3 papers estimate the effect of biological factors on the downward and upward movements of water in the vadose zone of soil, and 2 papers evaluated the amount of greenhouse gas emissions from agriculturally utilized soil and forest fires. We would like to conclude by expressing our hope that the papers published in the present special issue will act as a stimulus for initiating new research projects and contribute to finding solutions to the global threats of water scarcity and soil degradation. It is absolutely crucial to increase our chances of surviving the current climate change and to reach a more sustainable society in the future.
\end{abstract}

Keywords Biohydrology $\cdot$ Biological factors $\cdot$ Hydrological processes

After 2 special issues (with 29 and 48 papers published in 2006 and 2009, respectively) and 6 special sections (with 55 papers published in 2007 and 2013-2017), this is the $3 \mathrm{rd}$ special issue on the impact of biological factors on hydrological processes published in Biologia. The fact that this journal has accepted over 15 years to publish 147 papers on biohydrology ( 3 papers were published in current issues in 2018 and 2019) appears as a very encouraging sign that two managing editors with vision (namely Prof. Igor Mistrík and Dr. Katarína Hegedüšová, respectively) were or are willing to

L'ubomír Lichner

lichner@uh.savba.sk

1 Institute of Hydrology, Slovak Academy of Sciences, Dúbravská cesta 9, 84104 Bratislava, Slovakia

2 Plant Science and Biodiversity Center, Institute of Botany, Slovak Academy of Sciences, Dúbravská cesta 9, 84523 Bratislava, Slovakia

3 Norwegian Institute of Bioeconomy Research, POB 115, NO-1431 Ås, Norway

4 Institute of Hydrodynamics, Czech Academy of Sciences, Pod Pat'ankou 30/5, 16612 Prague 6, Czech Republic

5 Institute of Soil Science and Agricultural Chemistry, Centre for Agricultural Research, Hungarian Academy of Sciences, Herman Otto Ut 15, Budapest H-1022, Hungary draw the readers' attention to this interdisciplinary research, and in this way to encourage the engagement of biologists in biohydrological research efforts at a larger scale (Baveye 2013). Many of 147 published works were presented at five biohydrology conferences held in Prague in 2006, in Bratislava in 2009, in Landau in 2013, in Almeria in 2016, and in Valencia in 2019, and the guest-editors of Biologia special issues and sections (Dr. Louis W. Dekker, Prof. Paul D. Hallett, Prof. Radka Kodešová, Dr. Lubomír Lichner, Dr. Viliam Novák, Prof. Kálmán Rajkai, Prof. Gabriele E. Schaumann, Dr. Miloslav Š́r, Prof. Jaroslav Škvarenina, and Dr. Miroslav Tesař) were the organizers of these conferences. The biohydrology papers published in Biologia in 15 years were written by the authors from 32 countries (Algeria, Australia, Austria, Belgium, Brazil, Czech Republic, Egypt, Estonia, Ethiopia, France, Georgia, Germany, Hungary, Iceland, India, Indonesia, Iran, Israel, Italy, Japan, The Netherlands, Norway, Poland, Russia, Slovakia, Slovenia, Spain, Sri Lanka, Sudan, Switzerland, United Kingdom, USA) on 5 continents, illustrating a worldwide growing trend in the scientific literature regarding the impact of biological factors on soil hydrology.

The present special issue on the impact of biological factors on hydrological processes, edited by the authors of this Foreword, brings together 11 full-text papers on these 
complex interactions. Four papers assess the impact of land use on soil properties. Fér et al. (2020) elucidated the influence of long-term ecological farming on selected soil properties by comparing results obtained in the field with continuous conventional farming (CT) and those obtained in the field where the original CT was converted into ecological farming system with no-till practice (NT) 12 years earlier. The authors found that NT increased soil water repellency and mostly had a positive influence on the soil quality. The soil water retention capacity represented by the saturated soil water content, the slope of the soil water retention curve at the inflection point and the hydraulic conductivity at the pressure head of $-2 \mathrm{~cm}$ were greater under NT than CT. It was concluded that ecological farming improved the soil chemical and hydrophysical conditions.

Rupasinghe and Leelamanie (2020) comparatively assessed municipal solid waste compost and agriculturebased waste compost considering their effects on soil acidity, salinity, fertility, and short-term crop yield response in a tropical Ultisol in Sri Lanka. The soil was initially acidic and nonsaline and $\mathrm{pH}$ significantly increased with the application of municipal solid waste compost, but not with agriculture-based waste compost. Municipal solid waste compost was comparable or better than agriculture-based waste compost considering the crop yield response. Hence, the use of municipal solid waste compost can be considered better suited for soils with more acidic conditions, until they met the safety and health requirements. The authors concluded that it is important to conduct further studies to investigate the impacts of longterm municipal soil waste application on the changes in soil physical, chemical and biological environment.

Šurda et al. (2020) estimated the differences in moisture pattern, hydrophysical and water repellency parameters of sandy soil under native (indigenous to the region) grassland at site $\mathrm{S} 1$ and synanthropic (occurring on the sites created or disturbed by man) grassland at site S2 in Sekule, Slovakia. They found that the greater organic carbon content at site S2 resulted in the greater repellency index and smaller hydraulic conductivity and sorptivity of water at site S2 in comparison to S1. Infiltration experiments revealed that the penetration of water was deeper at $\mathrm{S} 1$ than at $\mathrm{S} 2(100 \mathrm{~cm}$ vs. $80 \mathrm{~cm})$, but the difference in soil water storage between 0 and $50 \mathrm{~cm}$ was not significant (35.1\% and $36.8 \%$ of applied water at S1 and S2, respectively). They concluded that under the studied conditions the soil water retention capacity does not depend on the type (native or synanthropic) grassland.

Zhang et al. (2020) assessed the effect of vegetation restoration to reduce soil and water loss on the Chinese Loess Plateau, where rainfall is the only water input to the soil. Most of the sloping farmlands of Loess Plateau were abandoned during recent decades in favour of grass or subshrub species or planted forests and shrubs. Different plant communities have varied water interception, root and soil properties, leading to various soil water input characteristics. Crops and Alfalfa often have high infiltration rates, and deeper wetting front. Pine plantation produced the highest surface runoff compared with the shrubs and native grasses. Although pine plantations may control water and soil loss, they compound soil compaction and desiccation, resulting in landscape degradation.

Next 3 papers estimate the impact of biological factors on the downward and upward movements of water in the vadose zone of soil. Acceleration of the downward movement of water in the soil (Haplic Chernozem) matrix by preferential flow at Most pri Bratislave, Slovakia, was studied by Šír et al. (2020). To determine the water content of the soil profile during water infiltration, the authors used the radioactive tracer technique with the radioactive iodine ${ }^{131} \mathrm{I}$ as a tracer and the Geiger-Müller tube as a detector of gamma radiation. They found that the gravity-driven fingers were formed in the soil under the grass cover due to saturation overshoot and the finger flow was manifested by the oscillatory discharge from the soil. The experiment has shown that both effects characterizing finger flow - the saturation overshoot and nonmonotonic shape of the moisture profile - could be recorded simultaneously.

The acceleration of the upward movement in the vadose zone of soil is caused by the uptake of water by plant roots. Enku et al. (2020) calculated the consumptive water use of a small Eucalyptus patch in the Fogera plain near Lake Tana, Ethiopia, from the fluctuating diurnal water table observations for two dry monsoon phases. They found that translating the changing groundwater levels in precise evapotranspiration rates was cumbersome because of uncertainty in the value of drainable porosity. They concluded that the evapotranspiration over the small Eucalyptus patch at the end of the dry phase was around $10 \mathrm{~mm} \mathrm{~d}^{-1}$, which is twice the reference evaporation rate. This is in accordance with advection aridity approach where the actual evaporation of isolated patches with access to groundwater in dry environments can evaporate at twice the reference rate.

Lichner et al. (2020) assessed the effect of water repellent vs. wettable top layers with different thickness on water evaporation from coarse and fine texture subsoils that were premoistened. Clay loam soil samples were taken from Pinus pinaster woodland of Ciavolo, Italy, and sandy soil samples from Pinus sylvestris woodland of Sekule, Slovakia. It was found that the clay loam soil coverage with the $0.3,1$, and $2 \mathrm{~cm}$-thick duff layers from Ciavolo resulted in prolonging the evaporation by 10,23 , and 37.5 days, respectively. As to the sandy soil from Sekule, the sandy soil coverage with the 0.3 , 1 , and $2 \mathrm{~cm}$-thick water repellent soil layers resulted in prolonging the evaporation by about 4,15 , and 22 days, respectively. It was concluded that water repellent surface layers, created by pine trees, are able to delay evaporation significantly for both coarse and fine textured soils, which 
may be particularly beneficial for plants during hot and dry periods in summer.

Two papers evaluate the amount of greenhouse gas emissions from agriculturally utilized soil and forest fires. It should be noted that greenhouse gases are the major cause of climate change, which intensifies the hydrological cycle because as air temperatures increase, more water evaporates into the air. Warmer air can hold more water vapor (the water holding capacity of air increases by about $7 \%$ per $1-^{\circ} \mathrm{C}$ increase in air temperature), which can lead to more intense rainstorms, causing more frequent floods. At the same time that some areas are experiencing stronger storms, others are experiencing more dry air, scarce precipitation and even drought (Stagl et al. 2014).

Rizhiya et al. (2020) studied the effect of a nitrogen enriched biochar mixed with compost in ratio 50:50 v/v on carbon dioxide $\left(\mathrm{CO}_{2}\right)$ and nitrous oxide $\left(\mathrm{N}_{2} \mathrm{O}\right)$ emission from Haplic Luvisol in a laboratory experiment. Application of biochar mixed with compost significantly decreased the cumulative $\mathrm{CO}_{2}$ (by $47-64 \%$ ) and $\mathrm{N}_{2} \mathrm{O}$ (by 62-77\%) fluxes compared to other treatments containing inorganic fertilizer (10\% ammonium sulfate solution, biochar $+10 \%$ ammonium sulfate solution, compost $+10 \%$ ammonium sulfate solution), and significantly increased concentration of ammonium nitrogen in the soil (by 16-21\%) compared to treatments with organic fertilizers (compost and compost + biochar). It was concluded that the application of biochar mixed with compost to the Haplic Luvisol presents environmental benefits to crop production, with the possibility for farmers to put higher concentrations of nutrients into the soil and restrict greenhouse gas emission from the soil.

Korísteková et al. (2020) evaluated the amount of potential greenhouse gas emissions from forest fires and the amount of biomass available for burning in the area of the Slovak Paradise National Park using the 2006 IPCC Tier1, Tier2, and Tier 3 methods and different structured and detailed input data. Based on the differences in calculated emissions the authors recommend to use Tier1 method (requiring the least input data and giving the least accurate results) for basic estimates of greenhouse gas emissions. More complex methods Tier2 and Tier 3 (giving more accurate results, but requiring more detailed input data) are recommended for determination of greenhouse gas emissions in case of large-scale fires, with the acreage over 10 ha, which are usually well documented.

It is well-known that lichens are capable of storing significant amounts of atmospheric water. In their "test-tube-scale biohydrology" paper, Klamerus-Iwan et al. (2020) investigated the differences in storing the water by three lichen species: Evernia prunastrii, Hypogymnia tubulosa and Platismatia glauca. In the laboratory experiment, samples of thalli were wetted with constant doses of water and weighed in order to determine the amount of water storage capacity from simulated rainfall. Average water retention was the highest in
Platismatia glauca (33.58\%), lower in Evernia prunastrii (19.77\%), and the lowest in Hypogymnia tubulosa (15.38\%). Differences in the process dynamics and water storage capacity were attributed to the morphological structure of thalli.

In his "regional-scale biohydrology" paper, Wine (2020) proposed criteria by which the broader hydrologic literature might be filtered to ensure that science that modifies water sharing in a water-scarce transboundary watershed does it on the basis of strong inference. By filtering studies that can impact transboundary water sharing and treasured aquatic ecosystems through the filter suggested by himself, not only can water sharing and management become more equitable, but the quality of the scientific literature in such domains may improve. Such a goal might be achieved by modifying existing water sharing agreements to state explicitly what attributes a hydrologic study must have such that it can be considered sufficiently compelling to modify a water sharing agreement.

The papers published in this special issue were written by the authors from 12 countries (Czech Republic, China, Ethiopia, Hungary, Israel, Italy, Norway, Poland, Russia, Slovakia, Sri Lanka, USA). The authors solved the problems ranging in scale from the water storage of water by lichen species (test-tube scale) to competition of the nations for increasingly scarce water resources in securitized transboundary watersheds (regional scale). In addition to these "boundaryscale" biohydrology papers, 4 papers assessed the impact of land use on soil properties, 3 papers estimated the impact of biological factors on the downward and upward movements of water in the vadose zone of soil, and 2 papers evaluated the amount of greenhouse gas emissions from agriculturally utilized soil and forest fires. We would like to conclude by expressing our hope that the papers published in the present special issue will act as a stimulus for initiating new research projects and contribute to finding solutions to the global threats of water scarcity and soil degradation. It is absolutely crucial to increase our chances of surviving the current climate change and to reach a more sustainable society in the future.

\section{References}

Baveye PC (2013) Addressing key challenges to interdisciplinary research on water-related issues: biologists' engagement and funding structure. Biologia 68(6):1087-1088

Enku T, Melesse AM, Ayana EK, Tilahun SA, Abate M, Steenhuis TS (2020) Groundwater use of a small Eucalyptus patch during the dry monsoon phase. Biologia 75(6)

Fér M, Kodešová R, Hroníková S, Nikodém A (2020) The effect of $12-$ year ecological farming on the soil hydraulic properties and repellency index. Biologia $(75,6)$

Klamerus-Iwan A, Kozłowski R, Przybylska J, Solarz W, Sikora W (2020) Variability of water storage capacity in three lichen species. Biologia 75(6) 
Korísteková K, Vido J, Vida T, Vyskot I, Mikloš M, Mind'áš J, Škvarenina J (2020) Evaluating the amount of potential greenhouse gas emissions from forest fires in the area of the Slovak paradise National Park. Biologia 75(6)

Lichner L', Alagna V, Iovino M, Laudicina VA, Novák V (2020) Evaporation from soils of different texture covered by layers of water repellent and wettable soils. Biologia 75(6)

Rizhiya EY, Horák J, Šimanský V, Buchkina NP (2020) Nitrogen enriched biochar-compost mixture as a soil amendment to the Haplic Luvisol: effect on greenhouse gas emission. Biologia 75(6)

Rupasinghe ISU, Leelamanie DAL (2020) Comparison of municipal and agriculture-based solid waste composts: short-term crop-yield response and soil properties in a tropical Ultisol. Biologia 75(6)

Šír M, Lichner L, Kmec J, Fürst T, Vodák R (2020) Measurement of saturation overshoot under grass cover. Biologia 75(6)

Stagl J, Mayr E, Koch H, Hattermann FF, Huang S (2014) In: Rannow S, Neubert M (eds) Effects of climate change on the hydrological cycle in Central and Eastern Europe, vol 58. Managing protected areas in Central and Eastern Europe under climate change. Advances in Global Change Research. Springer, Dordrecht, pp 31-43

Šurda P, Lichner L', Kollár J, Nagy V (2020) Differences in moisture pattern, hydrophysical and water repellency parameters of sandy soil under native and synanthropic vegetation. Biologia 75(6)

Wine ML (2020) Toward strong science to support equitable water sharing in securitized transboundary watersheds. Biologia 75(6)

Zhang XL, Zhang GD, Hu CH, Ping JH, Jian SQ (2020) Response of soil moisture to landscape restoration in the hilly and gully region of the loess plateau, China. Biologia 75(6)

Publisher's note Springer Nature remains neutral with regard to jurisdictional claims in published maps and institutional affiliations. 